\title{
The impact of Ramadan on peptic ulcer perforation
}

\author{
Peptik ülser perforasyonuna Ramazan'in etkisi
}

\author{
Ali Kağan GÖKAKIN, Atilla KURT, Mustafa ATABEY, Ayhan KOYUNCU, \\ Ömer TOPÇU, Cengiz AYDIN, Metin ŞEN, Gündüz AKGÖL
}

\section{BACKGROUND}

Medical treatment has played an important role in the reduction of peptic ulcer perforation (PUP). The goal of this study was to evaluate the effect of fasting on PUP.

\section{METHODS}

A retrospective analysis of 229 patients who were operated due to PUP between 1999-2009 was made. Patients were divided into two groups. Group I $(n=188)$ included the patients who were operated in other periods of the year, while Group II $(n=41)$ included the patients who were operated during Ramadan, the Muslim period of fasting. Patients in Group II were analyzed in terms of duration of fasting.

\section{RESULTS}

The increase in surgeries per group was higher in Group II than Group I $(\mathrm{p}<0.05)$. Predisposing factors, anti-ulcer drug usage and demographic variables were seen to have no role in this difference. Duration of fasting may have a minimal effect on the perforation.

\section{CONCLUSION}

The results of this study demonstrate that PUP is detected as relatively higher during Ramadan among those who are fasting for more than 12 hours daily. We suggest that people with predisposing factors should be informed before making a decision to fast.

Key Words: Acute abdomen; peptic ulcer perforation; prolonged fasting; Ramadan; urgent surgery.

\section{$\boldsymbol{A M A C}$}

Medikal tedavi peptik ülser perforasyon (PÜP) oranlarının azalmasında önemli bir rol oynamıştır. Bu çalışmada, Ramazan ayının PÜP üzerine olan etkisi değerlendirildi.

\section{GEREÇ VE YÖNTEM}

PÜP nedeniyle 1999-2009 y1lları arasında ameliyat edilen 229 hastanın dosyaları geriye dönük olarak analiz edildi. Hastalar iki gruba ayrıldı. Grup I (n=188) Ramazan ayı dişında ameliyat edilen hastalar, Grup II (n=41) Ramazan ayında, müslümanların oruç tutma döneminde ameliyat edilen hastalar. Grup II'deki hastalar oruç tutma sürelerine göre de değerlendirildi.

\section{BULGULAR}

Grup başına düşen ameliyat sayısı Grup II'de daha fazla idi $(\mathrm{p}<0.05)$. Bu farkın oluşmasında predispozan faktörler, antiülser ilaç kullanımı ve demografik özelliklerin rolü olmadığg saptand1. Oruç tutma süresinin perforasyon üzerine küçük bir etkisi olabileceği görüldü.

\section{SONUÇ}

Bu çalışmanın verileri Ramazan orucunun günde 12 saatten daha fazla sürdüğü dönemlerde PÜP'nin rölatif olarak daha fazla görüldüğünü göstermektedir. Predispozan faktöktörü olan hastaların oruç kararı öncesi bilgilendirilmesi gerektiği kanısındayız.

Anahtar Sözcükler: Akut karın; peptik ülser perforasyonu; uzamış açlık; Ramazan; acil cerrahi.
The therapeutic options in peptic ulcer disease, which includes ulcers of the duodenum and stomach, continue to be ameliorating due to the progress in surgical techniques, microbiology, and drug therapy. Yet, there is still a debate regarding the proper management of complicated peptic ulcer disease and, in particular, of those that are perforated. ${ }^{[1]}$ A variety of therapeutic approaches have been offered for the treatment of peptic ulcer perforation (PUP) in the literature, such as nonoperative management, laparoscopic repair and upper midline laparotomy. ${ }^{[2-5]}$ However, the routine treatment for perforated peptic ulcer still seems to be
Department of General Surgery,

Cumhuriyet University Faculty of Medicine, Sivas, Turkey.
Cumhuriyet Üniversitesi Tıp Fakültesi, Genel Cerrahi Anabilim Dalı, Sivas.

Correspondence (İletişim): Ali Kağan Gökakın, M.D. Cumhuriyet Üniversitesi Tıp Fakültesi Genel Cerrahi Anabilim Dalı, 058140 Sivas, Turkey. Tel: +90 - 346 - 2580491 e-mail (e-posta): dralihan20@hotmail.com 
by upper laparotomy, representing the main motive for reviewing the literature. ${ }^{[6]}$

The introduction of proton pump inhibitors and $\mathrm{H} 2$ antagonists into clinical use together with the recognition of Helicobacter pylori have caused a dramatic improvement in the medical management of uncomplicated peptic ulcer. In fact, the surgical approach to uncomplicated peptic ulcer disease has basically disappeared.

The cause of the perforation is unclear, but smoking, alcohol, non-steroidal antiinflammatory drug (NSAID) medication, and $H$. pylori infection have been identified as facilitating factors in many publications. ${ }^{[7-11]}$ Up to $30 \%$ risk of mortality can be seen in surgery for perforated ulcer. ${ }^{[12,13]}$

The factors that could be associated with mortality and morbidity in this group of patients have been the subject of many retrospective and prospective studies. Age, gender, type of surgery, chronic disease, drug and alcohol use, duration of perforation, blood pressure, concomitant disease, renal failure, and liver cirrhosis have been detected as the factors associated with morbidity in various publications. ${ }^{[14-22]}$

Fasting during the ninth month of the lunar calender (Ramadan) is a religious obligation for all adult Muslims. This entails no food or liquid intake from sunrise to sunset. The duration of this restriction varies between 10 to 19 hours depending on the season of the solar calendar in which Ramadan coincides that year (approximately 10 days earlier every year). The effect of Ramadan on the metabolism of the body has been the subject of various publications. ${ }^{[23-28]} \mathrm{An}$ association between time-restricted food and water intake and gastric $\mathrm{pH}$ and plasma gastrin level has been known for a long time. ${ }^{[29]}$

However, some particular effects of this religious ritual on PUP have not been thoroughly studied in recent years. Furthermore, an ongoing debate remains on peptic ulcer patients as to whether or not they may fast during Ramadan. This study was organized to evaluate the impact of Ramadan on PUP by considering the medical conditions of the patients and the duration of the fasting period (daylight) during Ramadan.

\section{MATERIALS AND METHODS}

The study was organized in a retrospective manner and involved 229 patients who were operated at our hospital for PUP between January 1999 and December 2009. Patients were divided into two groups. Group I included the patients who were operated in the months other than Ramadan (110 months during the study period), while Group II included the patients who were operated and declared their fasting during Ramadan (10 months during the study period). Any medical conditions of the patients that may have had an effect on the perforation, such as age, gender, period of time, concomitant disease, use of anti-ulcer drugs at the time of admission, and duration of daylight during the month of Ramadan were evaluated.

\section{Statistics}

We applied SPSS (Statistical Package for the Social Sciences) for Windows 15.0 for statistical analysis. The results were shown as percentages or median, minimum and maximum. Categorical data were analyzed statistically with chi-square. Continuous data were evaluated using Mann-Whitney U test.

\section{RESULTS}

Groups I and II included 188 (82.1\%) and 41 $(19.9 \%)$ patients, respectively. The number of surgeries per group was statistically significantly higher in Group II compared to Group I $(p<0.05)$. In the study, covering 120 months, both groups were exam-

Table 1. Distribution of operations per month

\begin{tabular}{lcccc}
\hline & $\begin{array}{c}\text { Total months } \\
(120 \text { Months })\end{array}$ & $\begin{array}{c}\text { Group I } \\
(110 \text { Months })\end{array}$ & $\begin{array}{c}\text { Group II } \\
(10 \text { Months })\end{array}$ & $p$ \\
\hline Number of cases & $229(100 \%)$ & $188(82.1 \%)$ & $41(17.9 \%)$ & \\
Mean value of operations per month & 1.90 & 1.70 & 4.10 & $\mathrm{p}<0.001$ \\
\hline Chi-square test. & & &
\end{tabular}

Table 2. Demographics of patients in groups

\begin{tabular}{lccc}
\hline & Group I & Group II & $p$ \\
\hline Age & $46(16-85)$ & $44(18-76)$ & 0.417 \\
Gender (Male/Female) & $165 / 23$ & $30 / 11$ & 0.017 \\
& $(87.8 / 12.2)$ & $(73.2 / 26.8)$ & \\
\hline
\end{tabular}

Mann-Whitney U and chi-square for age and gender, respectively. 
Table 3. Clinical features of patients

\begin{tabular}{lccc}
\hline & Group I & Group II & $p$ \\
\hline Generation & & & \\
$\quad$ Young adult & $132(70.22)$ & $33(80.49)$ & 0.184 \\
$\quad$ Geriatric & $56(29.79)$ & $8(19.52)$ & \\
Medication & & & \\
$\quad$ Positive & $36(19.15)$ & $8(19.52)$ & 0.957 \\
$\quad$ Negative & $152(80.86)$ & $33(80.49)$ & \\
Comorbidity & & $17(41.47)$ & 0.456 \\
$\quad$ Positive & $90(47.88)$ & & \\
\hline Chi-square test. & & & \\
& & &
\end{tabular}

Table 4. Impact of the length of fasting time on perforation in Group II

\begin{tabular}{lccc}
\hline Duration & $\mathrm{n}$ & $\%$ & $p$ \\
\hline More than 12 hours & 33 & 80.5 & \\
Less than 12 hours & 8 & 19.5 & $\mathrm{p}<0.001$ \\
Total & 41 & 100 & \\
\hline
\end{tabular}

Chi-square test.

ined in terms of the number of operations per month, and the number was statistically significantly higher in Group II (Table 1). Overall hospital mortality rate was detected as six $(2.6 \%)$ during the study period.

The ages of the patients ranged from 16 to 85 years (median: 45.0 [16-85]). The majority of the patients were male $(\mathrm{n}=195,85.2 \%)$ and younger than 60 years $(\mathrm{n}=165,72.1 \%)$. There was no difference between the two groups in terms of age $(p=0.417)$, but the number of males was significantly higher in Group II $(p=0.017)$. The incidence of perforation was detected as higher in young adults when the patients were analyzed according to their generation (older or younger than 60 years), but the difference was not statistically significant (Table 2).

In both groups, the majority of patients were not using any anti-ulcer drug $(\mathrm{H} 2$ receptor blocker, proton pump inhibitor or antibiotics for $H$. pylori eradication) $(80.86 \%, 80.49 \%$ in Groups I and II, respectively) at the time of admission. Approximately one of two patients in each group (44\% of all patients) had at least one concomitant disease. However, both comorbidities and anti-ulcer therapy usage at the time of admission were detected as ineffective in terms of statistical meaning between the two groups (Table 3 ).

The duration of fasting was analyzed in Group II patients, and PUP was found to be significantly higher in the patients who fasted more than 12 hours $(\mathrm{p}<0.001)$ (Table 4).

\section{DISCUSSION}

The question of whether or not fasting should be recommended to peptic ulcer disease patients is difficult because the physiological changes during Ramadan are not precisely known. The goal of this study was to evaluate the effect of Ramadan fasting on the occurrence of PUP.

In the modern era of H2-receptor blocker/proton pump inhibitor and $H$. pylori eradication treatment for peptic ulcer disease, there has already been a sharp decline in the elective treatment of such diseases. On the other hand, during this time, there has been no fall in the rates of PUP. Perforation of an ulcer is one of the most serious complications of peptic ulcer disease and has a great potential risk of morbidity and even lethality. The risk of this lethality lasted until the turn of the twentieth century when surgical treatment became available. ${ }^{[30,31]}$ The overall hospital mortality rate was six $(2.6 \%)$ in our study. This rate of mortality is acceptable and compatible with the literature..$^{[9,16]}$

It is well known that gastrointestinal disorders can be altered by fasting. Recently, only a few studies have focused on the impact of Ramadan on peptic disorders, and these have all reported different results. ${ }^{[23,26]}$

In our study, both groups were examined in terms of the number of operations per month per group. The number of operations was significantly higher in Group II $(\mathrm{p}<0.05)$, and these results seem consistent with previous studies. ${ }^{[32,33]}$

Peptic ulcer disease is mostly seen in male adults. $[7,9,12,16,17]$ The incidence of perforation was detected as higher in young adults in our study when the patients were analyzed according to their generation 
(as older or younger than 60 years), but no statistical significance was found. However, interestingly, the number of males were significantly higher in Group II $(p=0.017)$. This male dominancy can be explained by the different gender conditions. Men have to continue this ritual through the month without a break. On the other hand, women are permitted a few days of break from the fast during their menstrual period.

Concomitant disease has been detected as a factor associated with incidence and morbidity in many publications. ${ }^{[19,20]}$ In our study, at least half of the patients suffered from a concomitant disease $(54.1 \%)$, but no difference was found between the two groups.

Prolonged fasting has been shown to affect many things including metabolic profiles, weight, kidney function, blood pressure, and diabetes mellitus control. ${ }^{[27,28]}$ Thus, it can easily be expected that the duration has an effect on the rates of perforation. When the impact of the duration of fasting was analyzed in Group II patients, PUP was found significantly higher in patients who were fasting more than 12 hours $(\mathrm{p}<0.001)$.

This study has some limitations. Acquisition of all the relevant data requires a perspective of 36 years because Ramadan completes its progression around the solar calender in 36 years. Furthermore, this study can reflect only the results of one region in Turkey, but there are more than one billion Muslims throughout the world who are fasting under different conditions and durations.

In conclusion, a significant difference was found in the frequency of PUP during Ramadan, especially when the period of fasting was longer than 12 hours. On the other hand, it seems safe for other individuals. Further studies are required to obtain more comprehensive results.

\section{REFERENCES}

1. Christensen A, Bousfield R, Christiansen J. Incidence of perforated and bleeding peptic ulcers before and after the introduction of H2-receptor antagonists. Ann Surg 1988;207:4-6.

2. Bhogal RH, Athwal R, Durkin D, Deakin M, Cheruvu CN. Comparison between open and laparoscopic repair of perforated peptic ulcer disease. World J Surg 2008;32:2371-4.

3. Song KY, Kim TH, Kim SN, Park CH. Laparoscopic repair of perforated duodenal ulcers: the simple "one-stitch" suture with omental patch technique. Surg Endosc 2008;22:1632-5.

4. Vaidya BB, Garg CP, Shah JB. Laparoscopic repair of perforated peptic ulcer with delayed presentation. J Laparoendosc Adv Surg Tech A 2009;19:153-6.

5. Songne B, Jean F, Foulatier O, Khalil H, Scotté M. Non operative treatment for perforated peptic ulcer: results of a prospective study. [Article in French] Ann Chir 2004;129:57882.

6. Bertleff MJ, Lange JF. Laparoscopic correction of perforated peptic ulcer: first choice? A review of literature. Surg Endosc
2010;24:1231-9.

7. Svanes C. Trends in perforated peptic ulcer: incidence, etiology, treatment, and prognosis. World J Surg 2000;24:277-83.

8. Doherty GM, Way LW. Stomach and duodenum. In: Doherty GM, Way LW, editors. Current surgical diagnosis and treatment. 11 th ed. New York: McGraw-Hill; 2003 p. 533-64.

9. M. Johnston D, Martin I. Duodenal ulcer and peptic ulceration. In: Zinner JZ, Schwartz SI, Ellis H, editors. Maingot's abdominal operations. 10th ed. Vol. 1., Connecticut: Appleton\&Lange; 1997. p. 941-70.

10. Irvin TT. Mortality and perforated peptic ulcer: a case for risk stratification in elderly patients. Br J Surg 1989;76:215-8.

11. Martin RF. Surgical management of ulcer disease. Surg Clin North Am 2005;85:907-29, vi.

12. Rajesh V, Chandra SS, Smile SR. Risk factors predicting operative mortality in perforated peptic ulcer disease. Trop Gastroenterol 2003;24:148-50.

13. Gisbert JP, Pajares JM. Helicobacter pylori infection and perforated peptic ulcer prevalence of the infection and role of antimicrobial treatment. Helicobacter 2003;8:159-67.

14. Chou NH, Mok KT, Chang HT, Liu SI, Tsai CC, Wang BW, et al. Risk factors of mortality in perforated peptic ulcer. Eur J Surg 2000;166:149-53.

15.Zittel TT, Jehle EC, Becker HD. Surgical management of peptic ulcer disease today-indication, technique and outcome. Langenbecks Arch Surg 2000;385:84-96.

16. Chalya PL, Mabula JB, Koy M, McHembe MD, Jaka HM, Kabangila R, et al. Clinical profile and outcome of surgical treatment of perforated peptic ulcers in Northwestern Tanzania: A tertiary hospital experience. World J Emerg Surg $2011 ; 6: 31$

17. Torab FC, Amer M, Abu-Zidan FM, Branicki FJ. Perforated peptic ulcer: different ethnic, climatic and fasting risk factors for morbidity in Al-ain medical district, United Arab Emirates. Asian J Surg 2009;32:95-101.

18. Kujath P, Schwandner O, Bruch HP. Morbidity and mortality of perforated peptic gastroduodenal ulcer following emergency surgery. Langenbecks Arch Surg 2002;387:298302.

19. Barut I, Tarhan OR, Cerci C, Karaguzel N, Akdeniz Y, Bulbul M. Prognostic factors of peptic ulcer perforation. Saudi Med J 2005;26:1255-9.

20. Lanas A. Gastrointestinal injury from NSAID therapy. How to reduce the risk of complications. Postgrad Med 2005; 117:23-8, 31.

21. Noguiera C, Silva AS, Santos JN, Silva AG, Ferreira J, Matos E, et al. Perforated peptic ulcer: main factors of morbidity and mortality. World J Surg 2003;27:782-7.

22. Mäkelä JT, Kiviniemi H, Ohtonen P, Laitinen SO. Factors that predict morbidity and mortality in patients with perforated peptic ulcers. Eur J Surg 2002;168:446-51.

23. Al-Hourani HM, Atoum MF. Body composition, nutrient intake and physical activity patterns in young women during Ramadan. Singapore Med J 2007;48:906-10.

24. Fedail SS, Murphy D, Salih SY, Bolton CH, Harvey RF. Changes in certain blood constituents during Ramadan. Am J Clin Nutr 1982;36:350-3.

25. Ramadan J, Telahoun G, Al-Zaid NS, Barac-Nieto M. Responses to exercise, fluid, and energy balances during Ramadan in sedentary and active males. Nutrition 1999; 15:735-9.

26. Larijani B, Zahedi F, Sanjari M, Amini MR, Jalili RB, Adibi $\mathrm{H}$, et al. The effect of Ramadan fasting on fasting serum glu- 
cose in healthy adults. Med J Malaysia 2003;58:678-80.

27. Al-Arouj M, Assaad-Khalil S, Buse J, Fahdil I, Fahmy M, Hafez S, et al. Recommendations for management of diabetes during Ramadan: update 2010. Diabetes Care 2010;33:1895902.

28. Ghouri N, Gatrad R, Sattar N, Dhami S, Sheikh A. Summerwinter switching of the Ramadan fasts in people with diabetes living in temperate regions. Diabet Med 2012;29:696-7.

29. Halberg F. Protection by timing treatment according to bodily rhythms-an analogy to protection by scrubbing before sur- gery. Chronobiologia 1974;1:27-72.

30. Jennings D. Perforated peptic ulcer. Lancet 1940;1:444.

31. Jennings D. Perforated peptic ulcer. Lancet 1940;1:395.

32. Bener A, Derbala MF, Al-Kaabi S, Taryam LO, Al-Ameri MM, Al-Muraikhi NM, et al. Frequency of peptic ulcer disease during and after Ramadan in a United Arab Emirates hospital. East Mediterr Health J 2006;12:105-11.

33. Jastaniah S, Al Naami MY, Malatani TM. Perforated duodenal ulcer in Asir central hospital. Saudi J Gastroenterol 1997;3:90-3. 